\title{
The Study on Tax Incentive Policies of China's Photovoltaic Industry
}

\author{
Jian $X u^{1, a}$, Zhenji Jin ${ }^{2, b, *}$ \\ ${ }^{1,2}$ Department of Economics and Management, Qingdao Agricultural University \\ Qingdao, China, 266109 \\ axujiansword@163.com, bzhenji12@aliyun.com \\ ${ }^{*}$ Corresponding author
}

Keywords: Photovoltaic industry, Tax incentive, Policy.

\begin{abstract}
This paper introduces the scholars' research findings on the effectiveness of tax incentive policies in the photovoltaic industry. Then, from the perspective of the tax burden of photovoltaic listed companies, this paper analyzes the status quo of tax incentives in China's photovoltaic industry. Through model analysis, the corresponding countermeasures are put forward to improve tax incentive policies.
\end{abstract}

\section{Introduction}

In October 2010, the State Council issued the Decision on Accelerating the Cultivation and Development of Strategic Emerging Industries, specifying seven industries as the leading economic driving forces. These industries consist of energy saving and environmental protection, new information technology, biotechnology, high-end equipment manufacturing, new energy, new materials and new energy vehicles. Thus, the development of strategic emerging industries has risen to the national strategic level. The photovoltaic (PV) industry has an important role in the new energy industry.

In fact, China's PV industry has evolved into an Original Equipment Manufacturer (OEM) industry and been in a dilemma. On the one hand, many enterprises import and process a large number of raw materials, which waste huge energy increasing the burden of energy saving. On the other hand, the domestic application of solar energy is restricted and many PV products export to foreign countries, which is not conducive to optimize energy consumption structure.

As an emerging industry, PV industry requires the government and policy supports in its infancy. However, whether policy supports are effective depends on the formulation and implementation of policies, especially in a systematic mechanism.

\section{Literature Review}

The domestic scholars make great researches on promoting the development of PV industry.

Shi Jingli (2008) found that China's PV market develops slowly and the fiscal policy framework for solar power is not systematic. Solar power requires combined fiscal policy supports, e.g. electricity price, subsidies, taxes and loans[1].

Liu Qingxin et al. (2009) considered that China's photovoltaic industry is still in its infancy and requires the supports of tax incentive policies[2].

Ma Shenghong et al. (2010) made some highly targeted scientific suggestions. He advocated to use large-scale photovoltaic grid connected system, and strengthen the construction of quality assurance system and monitoring mechanism[3].

Wang Lining (2011) analyzed the deficiencies of current PV industry policy, and pointed out that the subsidy policies are imperfect and related regulations are inappropriate[4].

Wang Haojun et al. (2012) argued that the financial supports and tax credits for PV industry are still inadequate using the SWOT method. Thus, he put forward seven corresponding countermeasures[5]. 
Through literature review, scholars mainly focus on the status quo, the deficiencies and the countermeasures. Few experts make an empirical analysis of the tax incentive policies in the PV industry.

\section{Analysis of the Tax Burden of PV Listed Companies}

\section{Indicator Description}

Table 1 shows the description and the formula of the indicators.

Table 1. Indicator definition

\begin{tabular}{|c|c|c|}
\hline Indicator & Description & Formula \\
\hline TTB & Total tax burden & Total tax revenue to main business income (\%) \\
\hline ITB & Actual income tax burden & Income tax to operating profit (\%) \\
\hline VTB & Value-added tax burden & Value-added tax to main business income (\%) \\
\hline BTB & Business tax burden & Business tax to main business income (\%) \\
\hline
\end{tabular}

Total tax revenue is defined as the sum of business tax and surcharges, income tax and value-added tax. The turnover tax can be calculated through the relationship between education surcharge and urban maintenance and construction tax. The value-added tax is defined as the business tax and consumption tax subtracted from the turnover tax.

\section{Sample Selection}

This paper uses the data of tax burden of ten PV listed companies at Shanghai and Shenzhen Stock Exchange as a sample to analyze the function of tax incentives.

\section{Calculation Results}

Table 2 shows the specific calculation results.

Table 2. Tax burden of each listed company (in the year of 2011 and 2012)

\begin{tabular}{|c|c|c|c|c|c|c|c|c|c|c|}
\hline 2011 & No.1 & No.2 & No.3 & No.4 & No.5 & No.6 & No.7 & No.8 & No.9 & No.10 \\
\hline TTB & 0.007493 & 0.007265 & 0.007313 & 0.012194 & 0.017531 & 0.018012 & 0.004904 & 0.036417 & 0.075559 & 0.051148 \\
\hline ITB & 0.134415 & 0.221262 & 0.121805 & 0.104805 & 0.120472 & 0.112363 & -0.004578 & 0.162769 & 0.147282 & 0.154241 \\
\hline VTB & 0.027031 & 0.027025 & 0.000546 & 0.033201 & 0.040425 & 0.028368 & 0.021078 & 0.031832 & 0.162792 & 0.059102 \\
\hline BTB & 0.000276 & $8.48 \mathrm{E}-06$ & $6.47 \mathrm{E}-05$ & 0.000527 & 0.000313 & $1.22 \mathrm{E}-05$ & 0 & 0.000558 & $2.61 \mathrm{E}-05$ & 0.000589 \\
\hline 2012 & No.1 & No.2 & No.3 & No.4 & No.5 & No.6 & No.7 & No.8 & No.9 & No.10 \\
\hline TTB & -0.059640 & 0.004463 & -0.002811 & 0.010908 & 0.019935 & -0.009021 & 0.004371 & -0.015494 & 0.023519 & 0.024926 \\
\hline ITB & 0.116413 & -0.012222 & 0.274637 & 0.126847 & 0.137645 & 0.214191 & 0.014897 & 0.070165 & 0.147198 & 0.121001 \\
\hline VTB & 0.052446 & 0.001993 & 0.002552 & 0.048250 & 0.036726 & 0.016680 & 0.028764 & 0.038944 & 0.036144 & 0.041526 \\
\hline BTB & 0.000221 & 0.000111 & 0.000371 & 0.000744 & 0.000185 & $1.31 \mathrm{E}-05$ & 0 & 0.001183 & 0.000118 & 0.001832 \\
\hline
\end{tabular}

\section{Analysis of the Results}

Total Tax Burden. In 2012, the total tax burden has four negative values. Then, these values and the corresponding data in 2011 are eliminated. In 2011, the median total tax burden is 0.014863 and the mean value is 0.028100 . While in 2012 the median value is 0.015422 and the mean value 0.014687. According to Fig. 1, the total tax burden in 2012 is lower than that in2011. Compared with the mean values in 2011 and 2012, the fluctuation in total tax burden is great.

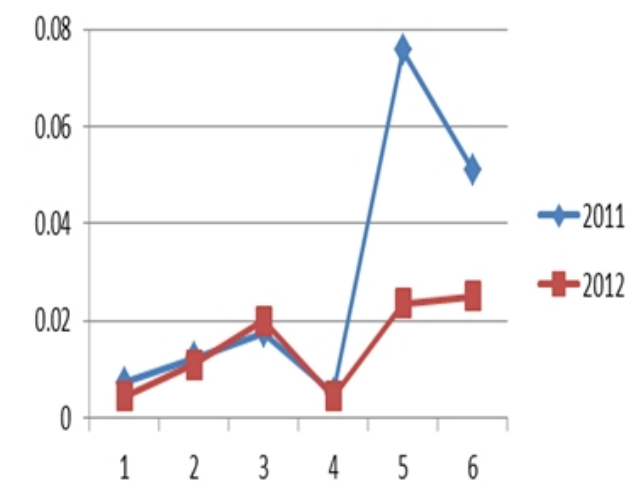


Figure 1. Corporate total tax burden (in the year of 2011 and 2012)

Income Tax Burden. In 2011, the negative value, the maximum value and the minimum value are eliminated. The median value is 0.134415 and the mean value is 0.136192 . While in 2012 , the median value is 0.126847 and the mean value is 0.133351 . Based on Fig. 2, corporate income tax burden in 2011 is more stable, fluctuating between 0.1 and 0.15 . However, the fluctuation in 2012 is great. Compared with the mean value in 2011 and 2012, we can see that the income tax burden in 2012 is lower.

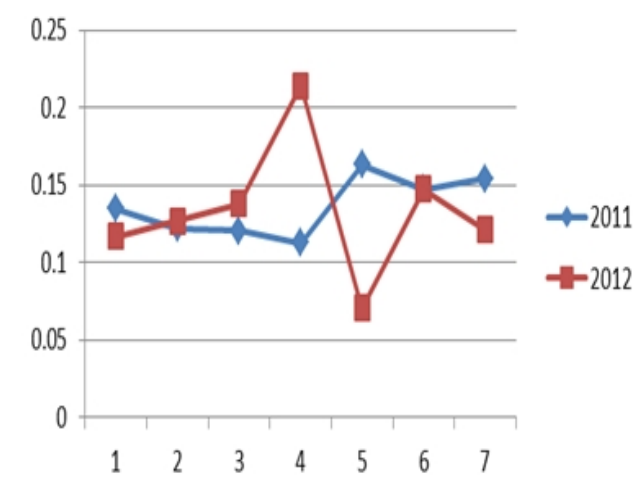

Figure 2. Corporate income tax burden (in the year of 2011 and 2012)

Value-added Tax Burden. Removing the maximum value and the minimum value, the median value in 2011 and 2012 is 0.0301 and 0.036435 respectively. The mean value in 2011 and 2012 is 0.046469 and 0.031198 . From Fig.3, we can see that corporate value-added tax burden is stable, fluctuating between 0 and 0.05 .

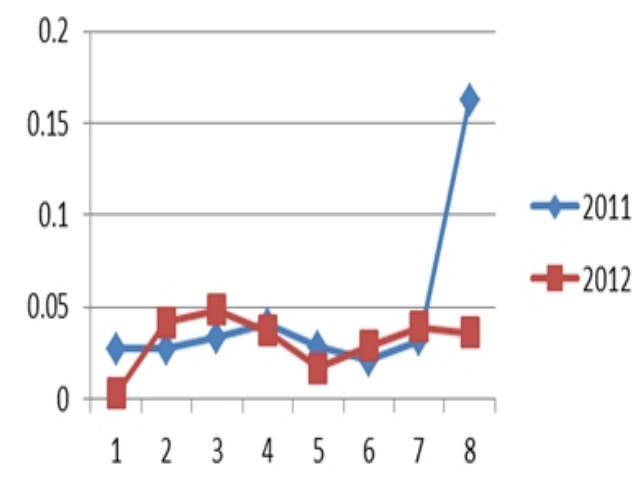

Figure 3. Corporate value-added tax burden (in the year of 2011 and 2012)

Business Tax Burden. From Table 1, it is found that the business tax occupies a small part of the overall tax burden and the tax burden is lower.

\section{Analysis of the Effectiveness of Tax Incentive Policies in Photovoltaic Industry}

Based on the relationship between the main tax revenue and the strategic emerging industries, the mathematical methods are adopted to make a further research on the impact of tax incentives on its development.

\section{Variable Selection and Definition}

Net profit is selected as a dependent variable. Value-addeed tax and business tax are the major categories in the turnover tax system. We treat them as the independent variables. Income tax, another independent variable, is the focus of the tax incentives, which has a direct impact on corporate profitability. The model is as follows.

$\operatorname{LnY}=\beta_{0}+\beta_{1} \operatorname{LnX} X_{1}+\beta_{2} \operatorname{LnX}_{2}+\beta_{3} \operatorname{Ln} X_{3}+\varepsilon$.

where $Y$ represents the net profit, $X_{1}$ the value-added tax, $X_{2}$ the business tax, $X_{3}$ the income tax, and $\varepsilon$ the error term. $\beta$ shows the impact of independent variables on the dependent variable. 
Using EViews analysis software and the ordinary least square (OLS) method, Table 3 shows the regression results.

Table 3. Regression results (1)

\begin{tabular}{|c|c|c|c|c|}
\hline Variable & Coefficient & Std.Error & t-Statistic & Prob. \\
\hline LnX $_{1}$ & 0.034571 & 0.029013 & 1.191535 & 0.2498 \\
\hline $\mathrm{LnX}_{2}$ & 0.047470 & 0.018986 & 2.500276 & 0.0229 \\
\hline $\mathrm{LnX}_{3}$ & 0.931745 & 0.043427 & 21.45550 & 0.0000 \\
\hline $\mathrm{C}$ & 1.827477 & 0.677282 & 2.698251 & 0.0152 \\
\hline R-squared & 0.976696 & \multicolumn{2}{|c|}{ Mean dependent var } & 19.27114 \\
\hline Adjusted R-squared & 0.972584 & \multicolumn{2}{|c|}{ S.D. dependent var } & 1.012996 \\
\hline S.E. of regression & 0.167730 & \multicolumn{2}{|c|}{ Akaike info criterion } & -0.563282 \\
\hline Sum squared resid & 0.478266 & \multicolumn{2}{|c|}{ Schwarz criterion } & -0.364325 \\
\hline Log likelihood & 9.914457 & \multicolumn{2}{|c|}{ F-Statistic } & 237.4998 \\
\hline Durbin-Watson stat. & 2.536188 & \multicolumn{2}{|c|}{ Prob(F-statistic) } & 0.000000 \\
\hline
\end{tabular}

In Table 3, the R-squared and the adjusted R-squared is about 0.97, indicating the Eq. 1 has the better fitting degree. The probability of the F-statistic is 0 , indicating that the entire equation is significant. The independent variable $\mathrm{LnX}_{1}$ is not significant $(\mathrm{t}=1.191535, \mathrm{p}>0.05)$. We remove the independent variable $\mathrm{LnX}_{1}$ and the regression results are as follows.

Table 4. Regression results (2)

\begin{tabular}{|c|c|c|c|c|}
\hline Variable & Coefficient & Std.Error & t-Statistic & Prob. \\
\hline LnX $_{2}$ & 0.051714 & 0.018865 & 2.741218 & 0.0134 \\
\hline LnX $_{3}$ & 0.951449 & 0.040620 & 23.42291 & 0.0000 \\
\hline C & 2.043963 & 0.660022 & 3.096812 & 0.0062 \\
\hline R-squared & 0.974750 & Mean dependent var & 19.27114 \\
\hline Adjusted R-squared & 0.971945 & \multicolumn{2}{|c|}{ S.D. dependent var } & 1.012996 \\
\hline S.E. of regression & 0.169674 & \multicolumn{2}{|c|}{ Akaike info criterion } & -0.578309 \\
\hline Sum squared resid & 0.518208 & \multicolumn{2}{|c|}{ Schwarz criterion } & -0.429092 \\
\hline Log likelihood & 9.072247 & \multicolumn{2}{|c|}{ F-Statistic } & 347.4377 \\
\hline Durbin-Watson stat. & 2.705153 & \multicolumn{2}{|c|}{ Prob(F-statistic) } & 0.000000 \\
\hline
\end{tabular}

In Table 4, the R-squared is 0.974750 and adjusted R-squared is 0.971945 , which is close to 1 , indicating the equation has a better fitting degree. The independent variables $\operatorname{Ln} X_{2}$ and $\operatorname{Ln} X_{3}$ are both significant. The value of Durbin-Watson statistics is 2.705133 , which is close to 2 , indicating that there is a slightly multi-collinear relationship. Thus, we get the following regression equation.

$\operatorname{LnY}=0.0517 * \operatorname{LnX}_{2}+0.9514 * \operatorname{LnX}_{3}+2.0439$.

From the regression results, the variables $\mathrm{LnX}_{2}$ and $\mathrm{LnX}_{3}$ reach the significant level of 5\%, indicating that the impact of the business tax and the income tax on strategic emerging industries is significant. The coefficients of the variables $\mathrm{LnX}_{2}$ and $\mathrm{LnX}_{3}$ are 0.0517 and 0.9514 respectively, indicating that the business tax and the income tax have a positive impact on the output of the emerging industries.

\section{Policy Implication}

The government should improve the tax policies for investment and consumption of strategic emerging industries, combined with domestic tax policies and the characteristics of strategic emerging industry.

\section{Value-added Tax}

The value-added tax burden of PV listed companies is 0.03 , which is reasonable. Thus, the general rate is 0.17 . First, the Tax Bureau considers the implementation of tax refund for the PV companies fully or partially. Second, non-profit organizations installing solar equipments should receive government subsidies or tax refunds to reduce costs[6]. Third, some discounts are given to highly-invested fixed assets prior to January 1, 2009. Finally, the labor costs of professionals who work in the western PV companies are deductible. 


\section{Corporate Income Tax}

The mean value of income tax burden in 2011 is 0.1362 and 0.1334 in 2012, indicating the income tax burden declines slightly. First, the tax of the first 5 years is exempt and the tax of the second 5 years is halved after receiving the profits. Second, personal income tax of private owned PV companies is exempt in order to encourage individuals to invest. Third, some emerging enterprises that are regulated in relevant provisions can have specific tax incentives.

\section{Business Tax}

The business tax burden of the listed companies is quite low. Business tax revenues only account for a very small part of the overall government revenues. Scientific institutions can apply to the local tax bureau to exempt the business tax when they engage in technology development, technology transfer and related technical consultancy services. Emerging industries may receive business tax refund purchasing fixed assets and intangible assets.

\section{Local Tax and Others}

First, the land use tax and the real estate tax are not levied on the land or the buildings for photovoltaic power generation. Second, vehicle and vessel use tax is exempt for the photovoltaic services. Third, the stamp taxes of the sales contract are exempt. Finally, the urban construction and maintenance tax and education surcharges of joint ventures and foreign-owned enterprises are not temporarily levied.

\section{References}

[1] Shi Jingli, Significance of international fiscal policy supports for solar power, Construction Science and Technology, China, 2008, pp. 83-85.

[2] Liu Qingxin, Ma Jian and Dong Jingjing, Discussion on tax policies of China's solar energy industry, Taxation Research, China, 2009, pp. 28-29.

[3] Ma Shenghong, Li Bin, Chen Dongbing, Chen Guangming, Sun Liping, Zhang Yabin, Xiong Yan and Liu Xin, Analysis of cost, price and technological progress of China's photovoltaic power generation, Solar Energy, China, 2010, pp. 6-13.

[4] Wang Lining, Policy analysis and countermeasures of China's photovoltaic industry, Solar Energy, China, 2011, pp. 16-18.

[5] Wang Haojun and Li Chen, Research on the fiscal and tax policies of China's solar energy industry, Friends of Accounting, China, 2012, pp. 83-85.

[6] Wang Wei, Countermeasures on the development of strategic emerging industry in Jiangxi -takes the photovoltaic industry as an example, Enterprise Economy, China, 2011, pp. 121-123. 